\title{
HAY AND PASTURE CROPS
}

\author{
IN \\ NORTHWESTERN \\ SASKATCHEWAN
}

BY

M. J. TINLINE, B.S.A.

Superintendent,

Dominion Experimental Station, Scott, Saskatchewan.

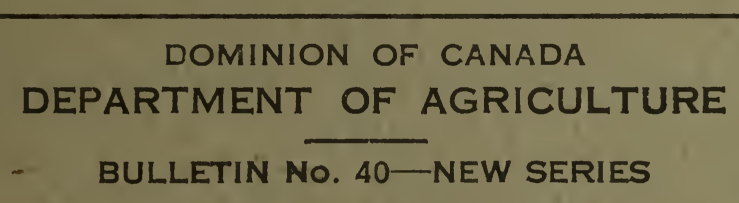

Agriculture

Canadian Agriculture Library

Bibliotheque canadienne de l'agriculture Ottawa K1A OC5 


\section{DOMINION EXPERIMENTAL FARMS BRANGH}

\section{PERSONNEL}

Director, E. S. Archibald, B.A., B.S.A.

Dominion Field Husbandman....................... S. Hopkins, B.S.A.,

Dominion Chemist........................................

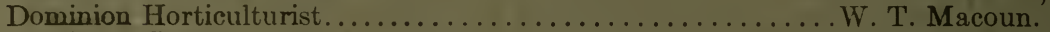

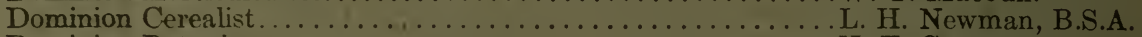

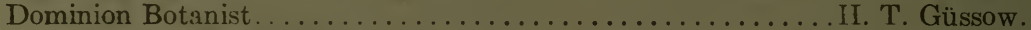

Dominion Animal Husbandman........................ B. Rothwell, B.S.A.

Dominion Forage Crop Specialist...................... M. McRostie, B.S.A., Ph.D.

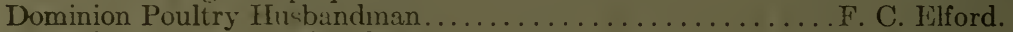

Dominion Tobacco Husbandman............................ M. Slagg, M.A., B.S.

Dominion Apiarist .................................. B. Gooderham, B.S.A.

Dominion Bacteriologist.................................. Grant Lochhead,

Chief Officer, Extension and Publicity ..................... C. Nunnick, B.S.A.

Chief Supervisor of Illustration Stations .....................

Economic Fibre Specialist....................... J. Hutchinson.

\section{ALBERTA}

Superintendent, Experimental Station, Lacombe, Alta., F. H. Reed, B.S.A.

Superintendent, Experimental Station, Letlibridge, Alta., W. H. Fairfield, M.Sc.

Superintendent, Experimental Sub-station, Beaverlodge, Alta., W. D. Albright.

Superintendent, Experimental Sub-station, Fort Vermilion, Alta., Robt. Jones.

\section{BRITISH COLUMBIA}

Superintendent, Experimental Farm, Agassiz, B.C., W. H. Hicks, B.S.A.

Superintendent, Experimental Station, Summerland, B.C., W. T. Hunter, B.S.A.

Superintendent, Experimental Station, Invermere, B.C., R. G. Newton, B.S.A.

Superintendent, Experimental Station, Sidney, B.C., E. M. Straight, B.S.A.

\section{MANITOBA}

Superintendent, Experimental Farm, Brandon, Man., W. C. McKillican, B.S.A. Superintendent, Experimental Station, Morden, Man., W. R. Leslie, B.S.A.

\section{SASKATCHEWAN}

Superintendent, Experimental Farm, Indian Head, Sask., N. D. McKenzie, B.S.A. Superintendent, Experimental Station, Rosthern, Sask., W. A. Munro, B.A., B.S.A. Superintendent, Experimental Station, Scott, Sask., M. J. Tinline, B.S.A.

Superintendent, Experimental Station, Swift Current, Sask., J. G. Taggart, B.S.A.

\section{NEW BRUNSWICK}

Superintendent, Experimental Station, Fredericton, N.B., C. F. Bailey, B.S.A.

NOVA SCOTIA

Superintendent, Experimental Farm, Nappan, N.S., W. W. Baird, B.S.A.

Superintendent, Experimental Station, Kentville, N.S., W. S. Blair.

\section{PRINCE EDWARD ISLAND}

Superintendent, Experimental Station, Charlottetown, P.E.I., J. A. Clark, B.S.A.

\section{ONTARIO}

Central Experimental Farm, Ottawa, Ont.

Superintendent, Experimental Station, Kapuskasing, Ont., S. Ballantyne.

Superintendent, Experimental Station, Harrow, Ont., D. D. Digges, B.S.A., M.S.A.

\section{QUEBEC}

Superintendent, Experimental Station, Cap Rouge, Que., G. A. Langelicr, D.Sc.A. Superintendent, Experimental Station, Lennoxville, Que., J. A. McClary.

Superintendent, Experimental Station, Ste. Anne de la Pocatićre, Que., J. A. Ste. Marie, B.S.A. Superintendent, Experimental Station, La Ferme, Que., P. Fortier, Agr.

Superintendent, Tobacco Experimental Station, Farnham, Que., J. E. Montreuil, B.S.A. 


\section{HAY AND PASTURE CROPS}

IN

\section{NORTHWESTERN \\ SASKATCHEWAN}

BY

M. J. TINLINE, B.S.A.

Superintendent,

Dominion Experimental Station, Scott, Saskatchewan.

\section{DOMINION OF CANADA DEPARTMENT OF AGRICULTURE BULLETIN No. 40-NEW SERIES}




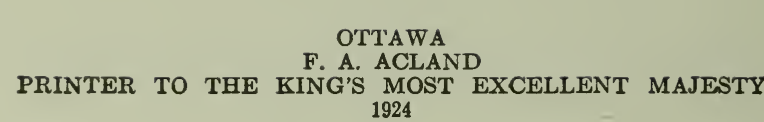




\title{
Hay and Pasture Crops in Northwestern Saskatchewan
}

\section{SUMMARY OF EXPERIMENTS}

BY

\author{
M. J. Tinline, B.S.A.
}

Grasses and leguminous crops have been under test on the Dominion Experimental Station at Scott since the Station was started in 1911. The first investigations were in the growing of western rye grass, alfalfa and red clover in combination on the rotation fields. In 1913 experiments were started to determine the best methods to employ in seeding down and to ascertain the most suitable kinds and varieties of grasses, clovers and alfalfa for the district. Later investigations included different methods of breaking the sod from these crops.

This experimental work is still under way but the demand for information on these subjects has been so great that it has been deemed advisable to summarize the information obtained to date and present it in bulletin form.

The annual precipitation has played an important part in determining the yields of hay and for this reason the total annual precipitation and the precipitation for the critical months of May, June, July and August are included herewith.

Precipitation Records

\begin{tabular}{|c|c|c|c|c|c|}
\hline Year & May & June & July & August & $\begin{array}{c}\text { Total } \\
\text { Annual Pre- } \\
\text { cipitation }\end{array}$ \\
\hline 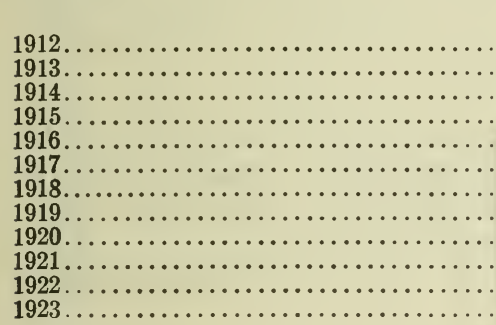 & $\begin{array}{l}\text { Inch } \\
2 \cdot 46 \\
0.95 \\
1.15 \\
1.40 \\
2.54 \\
0.41 \\
0.18 \\
0.88 \\
0.55 \\
1.39 \\
2.03 \\
0.94\end{array}$ & $\begin{array}{l}\text { Inch } \\
2 \cdot 19 \\
0 \cdot 28 \\
2 \cdot 37 \\
3 \cdot 54 \\
4 \cdot 23 \\
0 \cdot 88 \\
0 \cdot 29 \\
0 \cdot 91 \\
2 \cdot 47 \\
1 \cdot 66 \\
0 \cdot 87 \\
5 \cdot 67\end{array}$ & $\begin{array}{l}\text { Inch } \\
6 \cdot 16 \\
2 \cdot 98 \\
1 \cdot 80 \\
2 \cdot 11 \\
4 \cdot 17 \\
1 \cdot 03 \\
1 \cdot 87 \\
0 \cdot 75 \\
3 \cdot 74 \\
1.65 \\
0 \cdot 26 \\
4 \cdot 25\end{array}$ & $\begin{array}{l}\text { Inch } \\
2 \cdot 93 \\
2 \cdot 62 \\
1 \cdot 41 \\
0 \cdot 48 \\
3 \cdot 87 \\
1 \cdot 16 \\
0 \cdot 93 \\
2 \cdot 56 \\
2 \cdot 37 \\
0 \cdot 56 \\
3 \cdot 04 \\
1 \cdot 45\end{array}$ & $\begin{array}{r}\text { Inch } \\
19 \cdot 83 \\
9 \cdot 84 \\
18 \cdot 22 \\
10 \cdot 51 \\
20 \cdot 84 \\
6 \cdot 56 \\
6 \cdot 78 \\
11 \cdot 16 \\
14 \cdot 33 \\
13 \cdot 48 \\
10 \cdot 38 \\
15 \cdot 41\end{array}$ \\
\hline
\end{tabular}

The history of the production of forage crops in northwestern Saskatchewan is similar to that of many other parts of the Prairie Provinces. When the Station was started in 1911 little was known regarding the agricultural possibilities of the district and the kinds of crops that would prove profitable. Native grasses thrived better than in the warmer districts further south. Due to the dry climate, the prairie grass cured standing and it was found that if fires. were controlled, the upland, when mown every third year, would give a fairly good crop on which animals thrived. Live stock had extensive areas to roam over so that pastures were no problem.

$79191-1 \frac{1}{2}$ 
However, the land was rapidly brought under cultivation, and in a comparatively short time, in the better districts, native hay and pasture became much less plentiful and many farmers were compelled to curtail their live stock operations. At the present time pasture is the controlling factor in live stock production on many farms. Cultivated grasses and other hay and pasture crops have increased in the province of Saskatchewan from 25,000 acres in 1913 to 257,000 acres in 1923, a tenfold increase. The increase in acreage in the next ten years should be many time greater if the present demand for information is any guide.

\section{GRASSES, CLOVERS, AND ALFALFA}

\section{GRASSES-TEST OF KINDS}

During the five-year period 1915 to 1919 inclusive, five kinds of grasses were grown under comparable conditions. Brome grass was not included in these tests owing to the possibilities of its spreading to nearby windbreaks and fruit plantations. It was, however, grown on another part of the Station using timothy for comparison. More recently brome has been included in the regular tests but some of the grasses included in the table following had been dropped from the lists before the brome was included.

Each year the grasses were sown on land that had been summer-fallowed the previous year and were sown without a nurse crop. The yields quoted are the weights of cured hay per acre.

Grasses-Test of Kinds

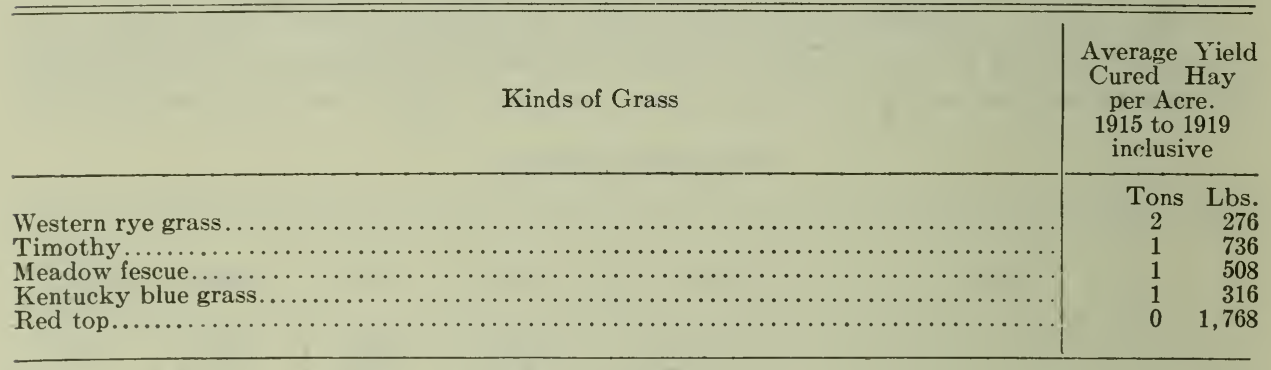

\section{DEDUC'TIONS}

(1) A good stand is more certain with western rye than with any of the other grasses, due to its being more winter hardy and more drought resistant.

(2) Meadow fescue makes a better after-cutting growth than most of the other grasses.

(3) Timothy, while second in point of yieid, is not to be recommended for districts with a light precipitation.

\section{COMPARISON OF WESTERN RYE GRASS AND BROME GRASS}

The test of brome grass and timothy conducted during the first years showed that in wet seasons such as 1916 the timothy outyielded the brome, while in the dry seasons the brome gave the better returns. In 1919 brome was first introduced into the regular test plots. The brome and western rye were sown each year on adjoining plots without a nurse crop. The plots were left for two cropping seasons and were then ploughed up and summer-fallowed for a season before being used for other experimental work. In the succeeding table the results from the first and second seasons are shown in separate columns. 
Western Rye Grass vs Brome for Hay

\begin{tabular}{|c|c|c|c|c|}
\hline \multirow{3}{*}{ Year Sown } & \multicolumn{4}{|c|}{ Yield per Acre Cured Hay } \\
\hline & \multicolumn{2}{|c|}{ Western Rye Grass } & \multicolumn{2}{|c|}{ Brome Grass } \\
\hline & 1st Crop & 2nd Crop & 1st Crop & 2nd Crop \\
\hline $\begin{array}{l}1919 \ldots \ldots \ldots \ldots \ldots \ldots \\
1920 \ldots \ldots \ldots \ldots \ldots \\
1921 \ldots \ldots \ldots \ldots \ldots \\
1922 \ldots \ldots \ldots \ldots \ldots\end{array}$ & $\begin{array}{r}\text { lb. } \\
4,440 \\
4,000 \\
2,720 \\
6,560 \\
\end{array}$ & $\begin{array}{c}\text { lb. } \\
5,320 \\
3,200 \\
4,040 \\
\ldots \ldots \ldots \ldots \\
\end{array}$ & $\begin{array}{l}\text { lb. } \\
2,000 \\
4,200 \\
2,400 \\
5,200\end{array}$ & $\begin{aligned} \text { Ib. } \\
5,560 \\
2,400 \\
4,000 \\
\ldots \ldots \ldots . .\end{aligned}$ \\
\hline Total yield... & 17,720 & 12,560 & 13,800 & 11,960 \\
\hline Average per acre... & 2 tons $430 \mathrm{lbs}$. & 2 tons $186 \mathrm{lbs}$ & 1 ton $1,450 \mathrm{lbs}$. & 1 ton $1,986 \mathrm{lbs}$. \\
\hline
\end{tabular}

From the results shown it will be noted that only in one year in the first crop of hay harvested, and in one year in the second crop, has the brome outyielded the western rye, while the average returns from the rye are considerably greater than from the brome. In the comparisons made between these two crops at Indian.Head Experimental Farm, the western rye has outyielded the brome in ten years out of fourteen. At the Brandon Farm, with its soil and local conditions, brome has given the best returns. It was observed in breaking up these two grasses that the western rye could be ploughed easily while the draft was much heavier in breaking the brome. One ploughing was not sufficient to destroy the brome and plants frequently persisted after both a breaking and back-setting. This experience would not likely be repeated on lighter soils, but on heavier soils greater difficulty might be anticipated.

\section{STRAINS OF WESTERN RYE GRASS}

The discovery by the Dominion Agrostologist that western rye grass was normally self-fertilized made the testing of this grass a comparatively simple matter. It also made possible the testing of many strains since self-fertilization is conducive to the establishing of strains that become fairly well fixed as to type. Collections were made from different parts of the Dominion and these were grown and studied on t: Central Experimental Farm, Ottawa. In 1920 the first strains of western rye were received at the Scott Station. In the first test, strains numbering from one to seven were grown for two seasons. Numbers 1, 2, and 3 proved low yielding and were discontinued. Strains number 4, 5, and 6 were continued and in 1921, strains 10, 11 and a commercial were added. The seed was sown in 1921 and in 1922 by hand to ensure uniform rates of seeding for each variety. In 1922 a total of 21 strains were included in the tests. As only one crop of the 1922 seeding has been harvested the newer introductions are not included in the succeeding table. The tests were arranged to compare each variety for both hay and seed production.

Western Rye Grass-Test of Strains

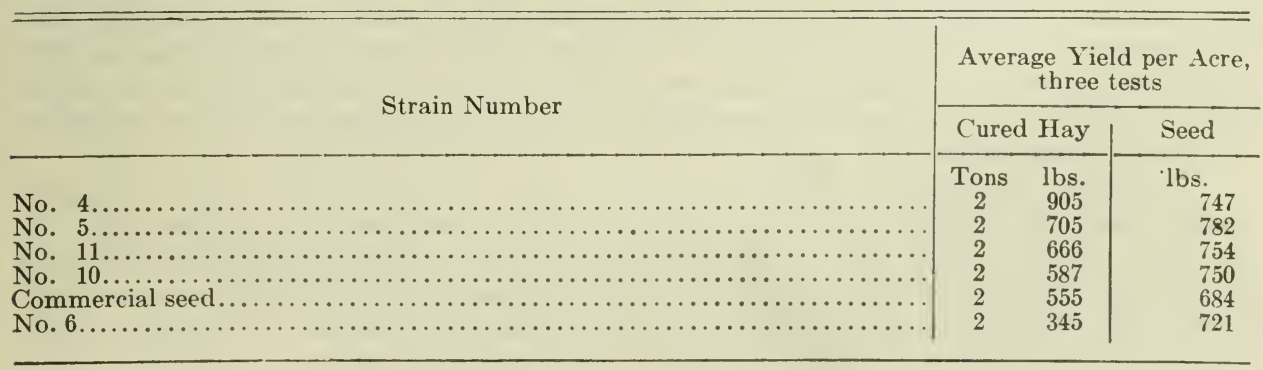


The number 4 strain has the highest yield of hay but is fourth in yield of seed. The No. 5 strain has been selected for multiplication, as it has a fine stem on which leaf growth is carried well to the top and produces a slightly heavier aftermath than most of the other strains tested. For the latter reason this strain has recently been named Grazer. From a 5-pound sample of this seed obtained from the Forage Crop Division, Ottawa, in 1921, a total of 3,461 pounds of seed has been threshed in two years. This is where the crop is grown in rows 36 inches apart.

\section{SWEET CLOVER}

This crop is rapidly assuming considerable importance in western agriculture. On the Station it has been found to be one of the heaviest yielding of the crops grown for hay and pasture. The test of varieties has been restricted to a single comparison of the white and yellow-blossom biennial types and the annual clover Hubam. The former type was represented by a selection made at the University of Saskatchewan and called by them Arctic. The yellowblossom Albotrea was received from a seed grower in Eastern Canada. There was a good growth the first season of the Arctic and a lesser growth of the Albotrea. Both were pastured quite closely late in the autumn. The season of 1922 was very dry, consequently the returns from all varieties were low. The seed of the biennial kinds was sown in June, 1921, while the Hubam was sown in late May, 1922. The former were ready to cut for hay in June, the latter in September.

Sweet Clover-Test of Variettes

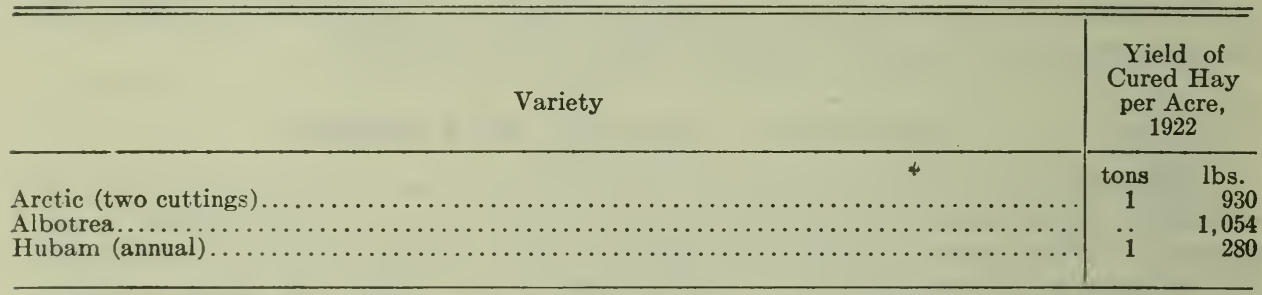

The Arctic sweet clover was only in the very beginning of the flowering stage when cut and was greatly relished by the calves receiving hay. The Albotrea was slightly farther advanced, the stems being more difficult to cut with the mower as they were less upright than the Arctic. Had the Hubam been sown earlier the returns might have been heavier, and the crop harvested earlier, which would have been advantageous from two standpoints-the crop would have been more easily cured in warmer weather and the labour of harvesting would have come at a less busy season.

\section{SWEET GLOVER-SEEDING ALONE AND WITH A NURSE CROP}

Sowing the biennial types of sweet clover alone is an expensive method unless some hay or pasture crop can be obtained the first year. In this district there is rarely sufficient moisture received to permit taking a crop of hay the first summer, and frequently it is not convenient to pasture the crop even though that should prove a profitable plan. For this reason seeding down with a nurse crop is likely to be the method generally adopted; particularly as it is considerably more economical.

In these experiments barley and oats were compared as nurse crop at several rates of seeding. In one rotation, wheat was used as a nurse crop for the sweet clover at the rate of one bushel per acre. In seeding down, the seed clover was mixed with the grain and sown through the grain drill. The tests were made on land that had been summer-fallowed the previous year. The sweet clover seed was used at the rate of 15 pounds per acre. 


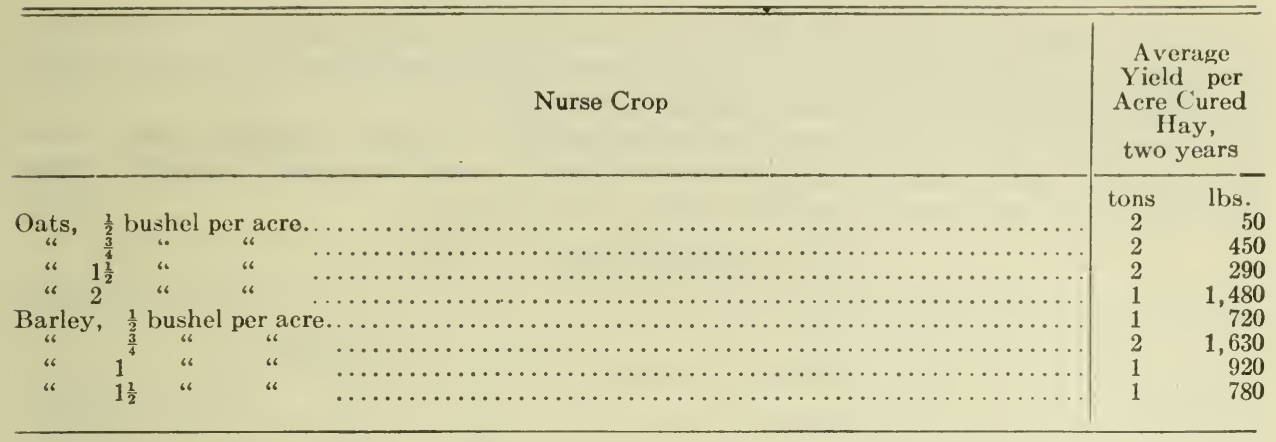

\section{DEDUCTIONS}

The two years' results show three-quarters of a bushel of either oats or barley as a nurse crop gives the best crop of sweet clover.

While a direct comparison of the wheat with oats or barley was not possible, the indications are that the wheat is the best crop to seed down with, particularly as the wheat is sown in April and early seeding appears to be advisable for sweet clover.

The loss in wheat from curtailing the quantity of seed, and the effect of the sweet clover on the crop, amounted on an average for a two-year period to $3 \frac{1}{2}$ bushels per acre.

Sweet clover in most seasons will not seriously affect the harvesting and threshing of the wheat crop in districts with a low annual precipitation.

Sweet Clover-In Grass Mixtures

\begin{tabular}{|c|c|c|c|}
\hline \multicolumn{2}{|c|}{ Rate of Seeding per Acre } & \multirow{2}{*}{\multicolumn{2}{|c|}{$\begin{array}{c}\text { Average Yield of Cured Hay per Acre, } \\
\text { two years }\end{array}$}} \\
\hline Quantity of Sweet Clover & $\begin{array}{c}\text { Quantity of West- } \\
\text { ern Rye }\end{array}$ & & \\
\hline $\begin{array}{c}\text { Ibs. } \\
12 \\
8 \\
8 \\
8 \\
10 \\
8 \\
6 \\
4\end{array}$ & $\begin{array}{r}\text { lbs. } \\
8 \\
4 \\
6 \\
8 \\
8 \\
10 \\
8 \\
8\end{array}$ & $\begin{array}{c}\text { tons } \\
3 \\
3 \\
2 \\
2 \\
2 \\
2 \\
2 \\
2\end{array}$ & $\begin{array}{c}\text { lbs. } \\
640 \\
20 \\
1,960 \\
1,940 \\
1,840 \\
1,620 \\
1,480 \\
1,480\end{array}$ \\
\hline
\end{tabular}

\section{DeduCTION}

The higher the percentage of sweet clover in the mixture the higher the yield of hay in the first crop.

Practically no sweet clover was found in the hay crop the second year. This is where scarified seed was used.

The best yield of hay in the second year was obtained by using a mixture of 10 pounds of western rye and 8 pounds of sweet clover.

The lowest yield resulted from using 8 pounds of western rye and 12 of sweet clover.

In a rotation experiment, 10 pounds of western rye and 6 of sweet clover has given good returns for a period of three years.

It would appear safe to assume that 10 pounds of western rye grass and from 6 to 8 pounds of sweet clover will prove to be about the best amounts for the drier districts. 


\section{ALFALFA FOR HAY}

The climate has proved rather dry for alfalfa, nevertheless, it is worthy of a place among the crops that may be grown because of the quality of the hay produced and the effect of the alfalfa on the soil.

The first alfalfa was started on the Station in 1913, when four plots were sown. The land had been summer-fallowed and ploughed deeply. Two varieties were compared, also the value of inoculation.

Test of Alfalfa

\begin{tabular}{|c|c|c|c|c|c|c|}
\hline \multirow{2}{*}{ Variety } & \multirow{2}{*}{ Method of Inoculation } & \multicolumn{5}{|c|}{ Yield per Acre } \\
\hline & & 1914 & 1915 & 1916 & Ave & rage \\
\hline 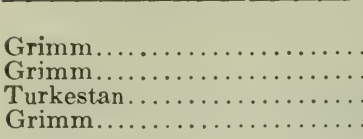 & $\begin{array}{l}\text { Soil inoculation ........... } \\
\text { Seed inoculation.......... } \\
\text { Soil inoculation ......... } \\
\text { No treatment.......... }\end{array}$ & $\begin{array}{l}\text { lbs. } \\
2,645 \\
2,634 \\
2,379 \\
1,445\end{array}$ & $\begin{array}{l}\text { lbs. } \\
2,031 \\
2,320 \\
2,147 \\
2,030\end{array}$ & $\begin{array}{l}\text { lbs. } \\
7,036 \\
6,566 \\
5,470 \\
6,369\end{array}$ & $\begin{array}{c}\text { tons } \\
1 \\
1 \\
1 \\
1\end{array}$ & $\begin{array}{l}\text { lbs. } \\
1,904 \\
1,840 \\
1,332 \\
1,281\end{array}$ \\
\hline
\end{tabular}

This experiment has shown that the Grimm is the hardier of the two varieties. It has shown that the introduction of the bacteria either by treating the seed or by applying soil from an old alfalfa field increases the yield. It is also interesting to observe that the yield from the plot receiving no treatment gradually increased each year, indicating that the bacteria gradually spread from the treated plots to the untreated. These plots were about one-quarter acre in size and about as long as wide.

\section{ALFALFA-BROADCAST SEEDING AND DRILLING}

A comparative test was made of broadcasting the alfalfa seed on the surface of the ground and harrowing the land after sowing, and mixing the alfalfa seed with cracked wheat and sowing through the grain drill. The land was summerfallowed the previous year and was in good tilth.

Alfalfa-Broadcasting the Seed vs. Drilling

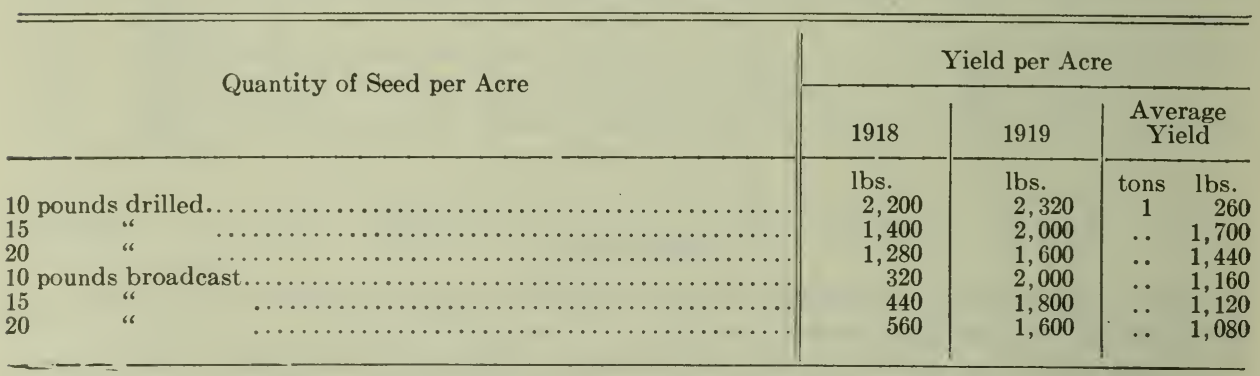

Two factors in alfalfa growing are brought out in this experiment: first, the importance of light seeding; second that it is necessary to put the seed into the ground, and not depend on the rains to germinate the seed and provide moisture for the young plants after they have started growth and before the rootlets have penetrated to the moister soil below. The order of the yields obtained in the first crop from broadcasting is difficult to explain, but they are so low that they plainly show this method of seeding alfalfa to be unsatisfactory in the drier districts. The experiences of many growers with grass and clover crops bear this out. 


\section{ALFALFA-DISTANCE APART FOR ROWS}

Alfalfa makes a valuable feed for young animals, pigs and poultry, and for this reason it was decided to try growing in rows and inter-tilling. The seed was sown in 1917 on summer-fallow land, consequently the yields obtained in the two succeeding years are a fair indication of what may be obtained under very dry conditions, as the precipitation was considerably below normal both years.

Alfalfa-Distance Apart for Rows

\begin{tabular}{|c|c|c|c|c|}
\hline \multirow{2}{*}{ Distance apart for Rows } & \multicolumn{4}{|c|}{ Yield per Acre } \\
\hline & 1918 & 1919 & $\begin{array}{l}\text { Ave } \\
\text { two }\end{array}$ & $\begin{array}{l}\text { rage, } \\
\text { years }\end{array}$ \\
\hline 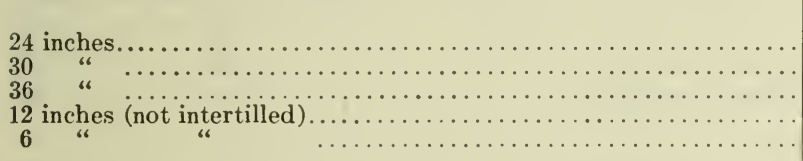 & $\begin{array}{l}\text { lbs. } \\
2,200 \\
1,640 \\
1,620 \\
2,400 \\
2,200\end{array}$ & $\begin{array}{l}\text { Ibs. } \\
3,600 \\
4,000 \\
2,400 \\
2,880 \\
2,320\end{array}$ & $\begin{array}{c}\text { tons } \\
1 \\
1 \\
1 \\
1 \\
1\end{array}$ & $\begin{array}{r}\text { lbs. } \\
1,040 \\
820 \\
10 \\
640 \\
260\end{array}$ \\
\hline
\end{tabular}

Two cultivations during the season were usually found sufficient to keep the weeds in control, once in the spring just as the growth commenced and once after the crop was removed. It will be noted that the 12-inch spaced rows gave slighly higher yields than where the rows were six inches apart and only half the amount of seed was required.

Two cuttings might be obtained in wet seasons when the crop is grown in rows, but it is scarcely safe in the northern districts to make two cuttings.

Cultivating the alfalfa where the rows were less than 24 inches was not practised at this Station. Experiments at other stations and tests made at Scott go to show that it is usually advisable to cultivate all alfalfa fields either after the crop is removed or first thing in the spring, or at both times. This may be done with the disc harrow run with the blades straight or with a narrow blade cultivator.

\section{TEST OF KINDS OF CLOVERS FOR HAY}

Red and alsike clover were extensively tested during the first trial year to ascertain if some strain could be obtained that would prove hardy in the north. While some winter-killing occurred, it was the lack of moisture that proved the greatest controlling factor. The yields were unprofitably low, consequently, after testing a number of strains obtained from different localities in America and Europe, these two crops were dropped from the list. During a later period, white dutch clover was tried but none of the strains came through the winter, although in moist places on the lawn at this Station the common white dutch has persisted, and in wet seasons forms a considerable part of the lawn mixture in these few spots. It may also be mentioned that in an old railway ditch near the Station, self-sown red clover and alsike have continued to grow for a period of years and in wet seasons make a good showing. Altaswede clover was only sown the one year. It made a strong growth in the autumn, but it failed to start the following spring.

\section{SEEDING DOWN PRACTICES}

Tests have been made to determine the effect of the nurse crop on a combinaof western rye grass and the legumes, and to determine the best time in the rotation to seed down. These experiments have now been underway for ten years. Formerly, alfalfa and red clover were mixed with the rye grass but later sweet clover has replaced the other legumes. The mixture as now used, is 
10 pounds of western rye and 6 of sweet clover. The nurse crop with one exception has been wheat, used at the rate of $1 \frac{1}{2}$ bushels per acre. The wheat and grass were sown together through the ordinary grain drill. Where the grasses and clover were sown without a nurse crop, cracked wheat was used to give bulk to the seed and the mixture was sown through the same drill.

Seeding Dow N Practices

\begin{tabular}{|c|c|c|c|c|}
\hline \multirow{2}{*}{ Place in Rotation } & \multicolumn{4}{|c|}{$\begin{array}{l}\text { Average Yield of Cured Hay } \\
\text { per Acre, ten years }\end{array}$} \\
\hline & \multicolumn{2}{|c|}{ Sown alone } & \multicolumn{2}{|c|}{$\begin{array}{l}\text { Sown with } \\
\text { Wheat }\end{array}$} \\
\hline 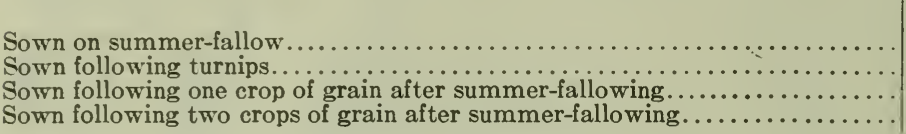 & $\begin{array}{c}\text { tons } \\
2 \\
1 \\
1 \\
1\end{array}$ & $\begin{array}{r}\text { lbs. } \\
448 \\
1,676 \\
1,520 \\
1,842\end{array}$ & $\begin{array}{c}\text { tons } \\
1 \\
1 \\
1 \\
1\end{array}$ & $\begin{array}{r}\text { lbs. } \\
1,332 \\
338 \\
288 \\
816\end{array}$ \\
\hline
\end{tabular}

\section{Deductions}

Seeding alone on summer-fallow has given the best returns, but not the most economical.

Following roots or grain crops, little advantage has been obtained by seeding alone.

In dry districts the nurse crop does not have as smothering effect upon the grass due to less rank growth as is the case in moister districts.

The seed can be sown deeper with a nurse crop than where it is sown alone. The grain crop opens the soil so that the more tender grass plants can reach the surface.

Good catches of grass and clover can be obtained with the third crop of grain after summer-fallowing, providing weeds are not a controlling factor and that the grass seed is sown early in the season on well-prepared land.

\section{PREPARATION OF SOD LAND FOR GRAIN GROPS}

An experiment to determine the best time to break sod land was started several years ago. During the first period the sod was that of western rye and alfalfa. While the alfalfa usually formed but a small part of the hay crop it proved very persistent when ploughed under, making both breaking and backsetting necessary. In some of the rotation experiments where western rye grass sod was ploughed in June and cultivated for the remainder of the season as summer-fallow, the grass was completely eradicated. The yield of wheat produced on the rye sod in a four-year period was 5 bushels per acre more than where wheat was grown on ordinary summer-fallow. It was found that the cost of preparing the sod land was less than the cost of preparing the ordinary summerfallow. It was observed that where sweet grass was prevalent in the rotation fields it spread to a noticeable extent during the time the fields were in grass. The importance of destroying all sweet grass or couch grass before seeding down and using seed free from these weeds cannot be over estimated. 


\section{ANNUAL HAY GROPS}

Annual crops for hay always play an important part in the production of fodder for live stock. They can be used to replace other fodder crops that fail, due to severe winters and other causes. Where a change in the farming policy necessitates an increase in the quantities of hay required, the annual crops will produce hay in from eighty to ninety days after seeding, whereas with such crops as alfalfa, the land is prepared one season, the seed sown the next and the crop harvested the third. The perennial crops that can be sown with a nurse crop, however, can be more cheaply seeded than the annual crops and require less labour to maintain a constant supply of feed.

In the experiments on the Station with annual crops for hay, the seed is sown about June 1 and on summer-fallowed land. Seeding on summer-fallow is found necessary to prevent volunteer grain growth.

Anndal Crops for Hay

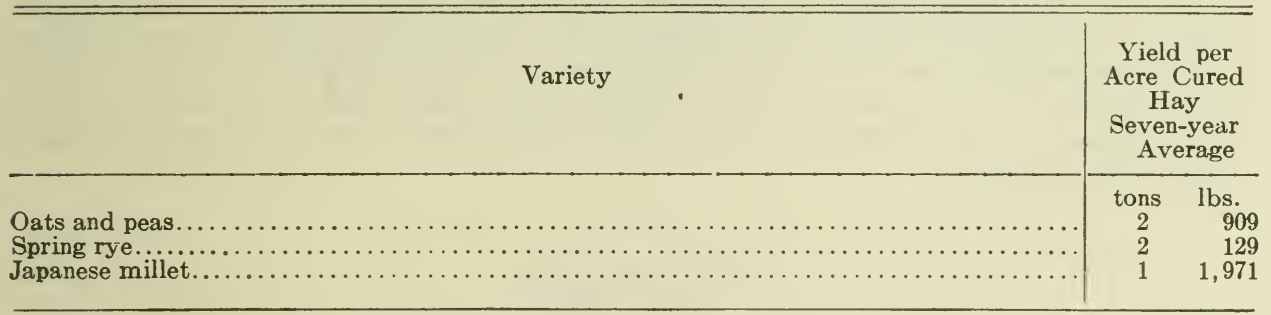

\section{Deductions}

Oats and peas in combination have outyielded all other crops.

It is only in the moister seasons that the peas make a considerable part of the mixture. A six-year average shows that oats alone yield almost as much as the oats and peas in combination.

Spring rye produces hay in less time than any of the other cured annual crops. The hay is not so palatable but is easily cured.

The early summer seasons in the north are too cool for best results with millets or sudan grass. It is only during the latter part of the summer that these thrive, and frequently they are not ready to cut before the time of grain harvesting.

\section{OATS FOR HAY}

Oats continue to be the staple annual crop on the farms for hay. They are used at all stages, from green cut oats that have scarcely reached the blossoming stage, to ripe sheaves. With a view to determining the best time to cut oats and the best varieties to use, an experiment was commenced on the Station in 1922. Seven varieties were sown and three plots of each variety. One plot was cut when the oats first commenced to bloom, the second when the oats were turning colour, and a third when the oats were ripe. Duplicate tests were made to ensure accuracy. The season was very dry, consequently the yields were light. 
OAts for Hay-Test of Varieties and Time to Cut

\begin{tabular}{|c|c|c|c|c|c|c|c|c|c|c|}
\hline \multirow{2}{*}{ Variety } & \multicolumn{10}{|c|}{ Yield of Hay per Acre weighed at Cutting Time } \\
\hline & \multicolumn{2}{|c|}{ In Bloom } & \multicolumn{2}{|c|}{ Aftermath } & \multicolumn{2}{|c|}{$\begin{array}{l}\text { When } \\
\text { turning }\end{array}$} & \multicolumn{2}{|r|}{ Ripe } & \multicolumn{2}{|c|}{$\begin{array}{l}\text { Average } \\
\text { Yield } \\
\text { per Acre }\end{array}$} \\
\hline 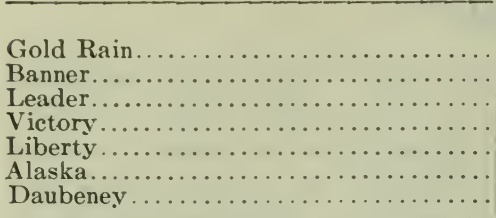 & $\begin{array}{l}\text { tons } \\
3 \\
3 \\
2 \\
3 \\
2 \\
2 \\
2\end{array}$ & $\begin{array}{r}\text { s lbs. } \\
592 \\
272 \\
1,120 \\
592 \\
1,056 \\
672 \\
32\end{array}$ & $\begin{array}{l}\text { tons } \\
1 \\
2 \\
2 \\
1 \\
\cdots \\
1 \\
1\end{array}$ & $\begin{array}{r}\text { s lbs. } \\
1,264 \\
544 \\
288 \\
784 \\
1,632 \\
1,856 \\
48\end{array}$ & $\begin{array}{c}\text { tons } \\
3 \\
2 \\
3 \\
2 \\
2 \\
1 \\
1\end{array}$ & $\begin{array}{r}\text { lbs. } \\
1,072 \\
1,632 \\
528 \\
1,344 \\
1,600 \\
624 \\
592\end{array}$ & $\begin{array}{l}\text { to } \\
2 \\
2 \\
1 \\
1 \\
1 \\
1 \\
\cdots\end{array}$ & $\begin{array}{r}\text { lbs. } \\
192 \\
16 \\
1,136 \\
1,888 \\
1,232 \\
400 \\
1,664\end{array}$ & $\begin{array}{l}\text { tons } \\
3 \\
3 \\
3 \\
3 \\
2 \\
1 \\
1\end{array}$ & $\begin{array}{r}\text { lbs. } \\
1,040 \\
821 \\
557 \\
203 \\
1,173 \\
1,851 \\
1,445\end{array}$ \\
\hline A verage yield of all varieties..... & 2 & 1,477 & 1 & 917 & 2 & 1,056 & 1 & 1,218 & 2 & 1,584 \\
\hline
\end{tabular}

The Gold Rain oats gave the heaviest yield in 1922 and again in 1923. Banner oats, that have given the best results from a seed production standpoint, were second both seasons in the total green weight produced.

\section{PEAS-VARIETIES OF PEAS FOR HAY}

This crop has only been under trial for hay on this Station for two seasons. The Arthur has the highest average yield for this period with the Early White second. The Prussian Blue is a longer-vined pea but the stem is more slender and consequently does not yield as well as the coarser-strawed Arthur. The yields generally from the peas have been much lower than the returns from oats, so that it is questionable if this crop will be used to any appreciable extent in the drier districts.

\section{PASTURES}

Pasture experiments are always difficult to conduct. First, there is the difficulty of obtaining a perfect stand of each crop; second, the difficulty of obtaining complete pasturing of the various crops. For these reasons the data contained in the following table can only be considered as indicating the comparative returns that may be expected from the crops tested.

The fields were about one acre each in area. The alfalfa and sweet clover had been sown alone in June of the previous year. The winter rye was sown in the month of August, and the western rye had been in sod for several years. Fifteen sheep were used in each field and when the pasture became too short they were weighed and put in a field of native pasture and when the pasture was sufficiently grown the same sheep were weighed back into the respective fields again. On the sweet clover, twelve additional sheep were required during the month of June to keep the crop from becoming too tall and woody.

Pastures for Sheep

\begin{tabular}{|c|c|c|c|c|}
\hline & $\begin{array}{l}\text { Sweet } \\
\text { clover }\end{array}$ & Fall rye & $\begin{array}{l}\text { Western } \\
\text { rye }\end{array}$ & Alfalfa \\
\hline 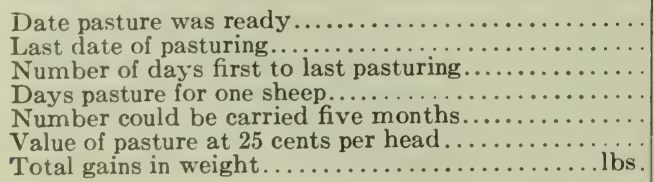 & $\begin{array}{r}\text { May } 27 \\
\text { Oct. } 3 \\
129 \\
774 \\
5 \cdot 2 \\
\$ 6 \quad 25 \\
441\end{array}$ & $\begin{array}{rr}\text { May } & 27 \\
\text { July } & 30 \\
64 \\
345 \\
2 \cdot 5 \\
\$ 250 \\
271\end{array}$ & $\begin{array}{r}\text { May } 15 \\
\text { Aug. } 13 \\
90 \\
593 \\
4 \cdot 7 \\
\$ 4 \\
25 \\
462\end{array}$ & $\begin{array}{r}\text { May } 27 \\
\text { Aug. } 6 \\
71 \\
435 \\
2 \cdot 05 \\
\$ 325 \\
472\end{array}$ \\
\hline
\end{tabular}


It will be noted that the sweet clover produced the greatest amount of pasture but that the gains in pounds of mutton were not as high as for the grass or alfalfa. This latter may be partly due to the sheep not being kept on this pasture continuously. The alfalfa made excellent pasture but the close pasturing resulted in much winter-killing, consequently the one season's crop was all that was obtained. The sheep did not relish the fall rye after the early summer.

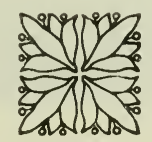




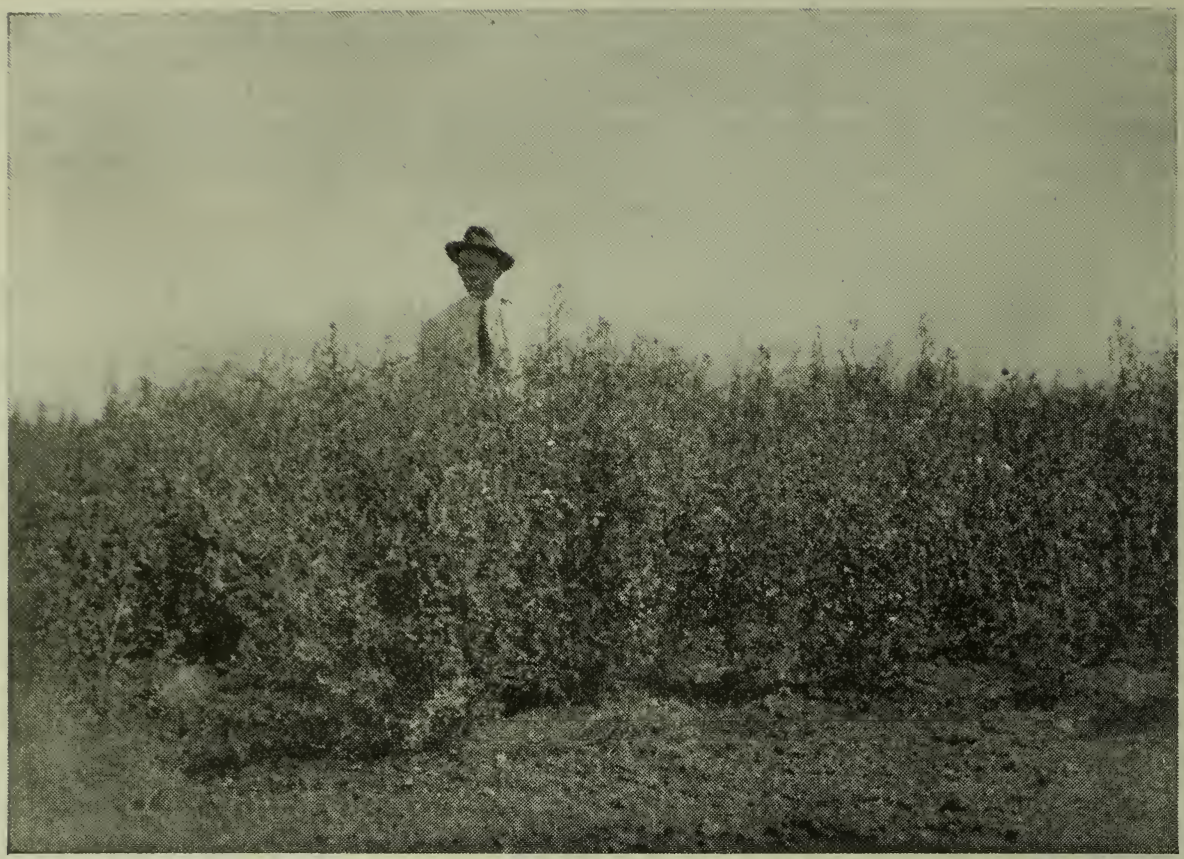

Arctic Sweet Clover for Seed.

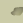

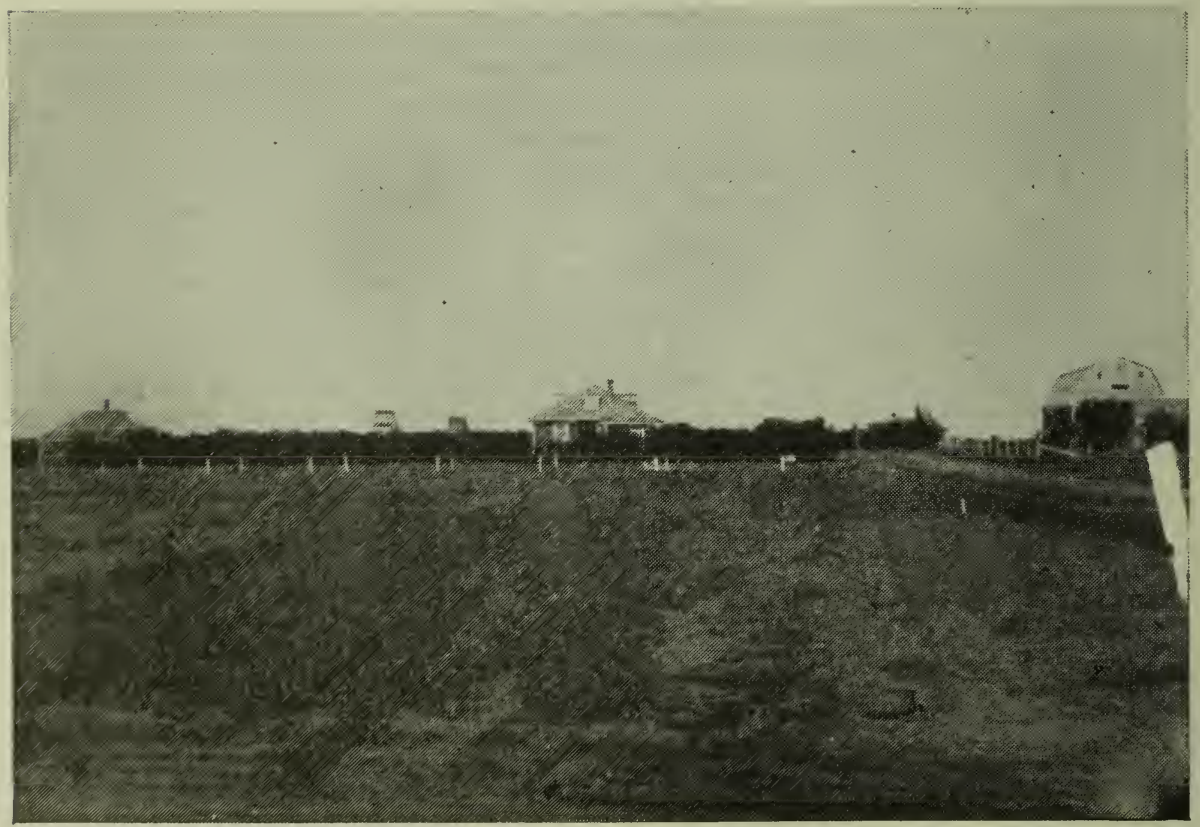

Western Rye Grass, on right, was killed with one ploughing. Brome Grass, on left; persists after same treatment. 


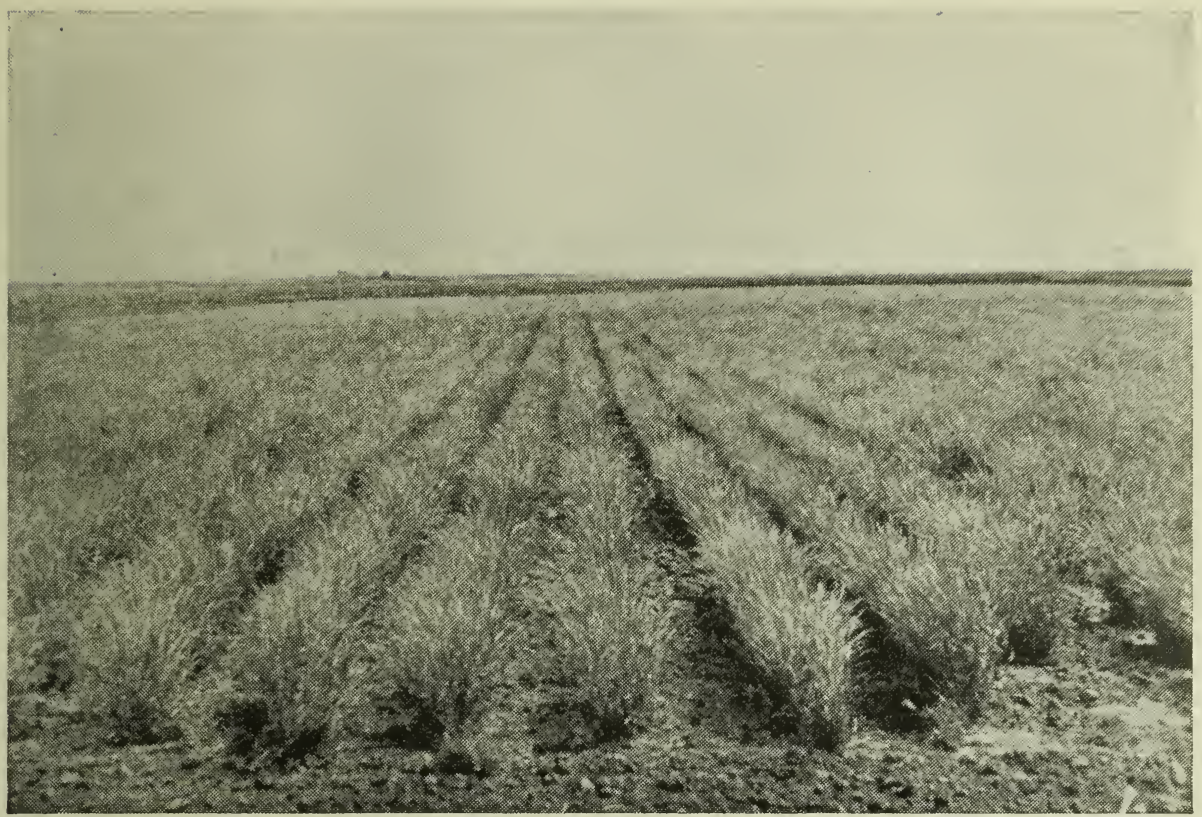

Three acres of Grazer Western Rye Grass. Yield from five pounds of seed was 3,461 pounds in two crops.

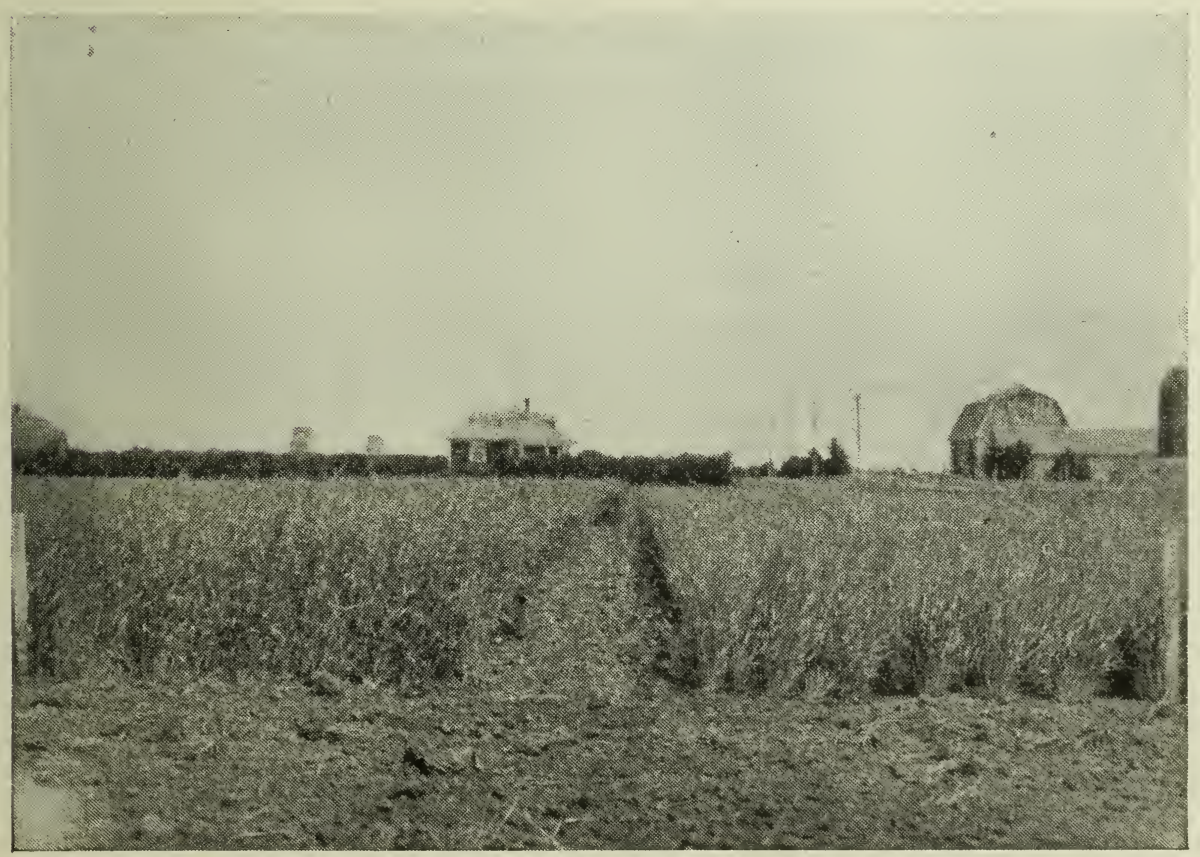

Plots of Brome Grass and Western Rye Grass. 


\section{PUBLICATIONS ON HAY AND PASTURE CROPS IN NORTHWESTERN SASKATCHEWAN}

Additional information relating to Hay and Pasture Crops in Northwestern Saskatchewan will be found in the Annual Reports of the Dominion Experimental Station, Scott, Saskatchewan.

Requests should be addressed to the

Publications Branch,

Department of Agriculture,

Ottawa. 

